\title{
Implementation of the Sustainable Development Goals as an opportunity for greater socio-economic integration within the European Union
}

\author{
Emilia BAMWENDA \\ Richard GIRLING \\ University of Wroclaw, Poland
}

\begin{abstract}
:
Aim: The aim of this article is to discuss the global and European concepts of sustainable development and how they can enhance European integration.

Design / Research methods: The analysis of statistical data will show positive and negative trends in Europe. In addition, barriers to the implementation of the sustainable development strategy will be indicated, as well as areas in which the EU should put more effort into achieving its ambitious goals.

Conclusions / findings: European Union countries stand out in the international arena for their high standard of living, made possible by a high level of economic development and extensive social welfare systems. However, at the turn of the 20th and 21st centuries it became clear that maintaining these high standards in the face of fundamental changes - both externally and internally - would require a significant reorientation of the current development policy. Euroscepticism, European integration, globalization and the increasing competitiveness of the rapidly growing Indian and Chinese economies, the IT revolution, the rise of the importance of knowledge and innovation, the prospect of depleting non-renewable natural resources crucial for modern development (combined with the associated risk in prices) are all becoming increasingly prominent in the list of challenges which Europe faces.
\end{abstract}

Originality / value of the article: The article discusses the current statistical data of the whole concept of sustainable development rooted in the Europe 2020 program in contrast to other, studies, which in the majority focus on one issue of European programs.

Implications of the research: This analysis complements the discourse regarding the Europe 2020 strategy.

Key words: Sustainable Development, European Union, European initiatives, integration, GDP. JEL: Q01, F15

Correspondence address: Emilia Bamweda, Richard Girling, University of Wroclaw, Poland. E-mail: ebamwenda@gmail.com, richard@ redcastleservices.com

Received: 06-09-2017, Revised: 18-12-2017, Revised: 13-02-2018, Revised: 20-02-2018, Accepted: 2002-2018

doi: http://dx.doi.org/10.29015/cerem.520 


\section{Introduction}

It can be argued that the European Union (EU) is in a state of crisis. Its ability to implement national reforms and its position as a global power are seriously undermined by internal forces within Europe and the risk that the EU will fall apart. Euroscepticism and populism are abundant; Reactions to the refugee crisis suggest that solidarity between Member States is poor; The euro crisis has deepened social tensions and economic divergences across the continent. Europe urgently needs a new and positive narrative for its future development which resonates with Europe's citizens and positions the EU as a constructive force for sustainable national and global development. This is even more urgent in the light of increasingly blurred boundaries between national and external agencies. It is not possible to promote Europe's sustainable development, nor its own interests, without considering the aspirations of emerging and developing countries. In addition to this, due to the size of its market and economy, European development decisions significantly affect the sustainability of other countries for better or worse. In 2030, the Sustainable Development Agenda with its 17 Sustainable Development Goals (SDGs) set the stage for national interdependence international policy making. Plan 2030 is a plan of action for people, planet, peace and prosperity that reflects fundamental European values and interests: it is crucial for Europe and the rest of the world.

This article will analyze statistical data from Eurostat and the resolutions of the Europe 2020 strategy, showing both positive and negative impacts on the economy and standard of living. Through this analysis, barriers to the implementation of the strategies become apparent, mainly consisting of the widening gap between rich and poor, which creates anti-European narratives. Today's European societies face many challenges related to sustainable development, from unemployment to aging populations, climate change, pollution, sustainable energy and migration. Europe must face the current challenges and strive to position itself for the future, bearing in mind the speed and complexity of changes in the era of globalization. In order to preserve European values and deepen integration, it is necessary to invest in social cohesion by investing in youth, social inclusion, sustainable growth and combating inequalities. In order to preserve and further develop the economy, changes in 
emissions, strong involvement in research and innovation, as well as the creation of new jobs are necessary. The integration of the Union requires ensuring coherence and cooperation between its various departments, as well as coherent actions between adopted policies. As part of the current trend, sustainable development is included in all key projects and development and integration initiatives.

\section{The history of sustainable development}

Sustainable development, as defined by the World Commission on Environment and Development in 1987, is a process aimed at satisfying the developmental aspirations of the young generation in a way that allows for the same aspirations for the next generations (The World Commission on Environment and Sustainable Development 1987: 41-42). The concept of sustainable development is - put simply - a concept that aims to improve economies through more efficient usage of natural resources, thereby simultaneously creating more environmentally friendly conditions and increasing the competitiveness of economies (Norgard 1995: 435).

The concept of sustainable development first came to light in 1968 during UNESCO's International Conference of Scientific Experts, devoted to the interconnectedness of the environment and development. The UN Secretary General's report, published in 1969, played a significant role in the international discourse on the risks of inappropriate resource management (Płachciak 2011: 239241). The breakthrough was the United Nations Conference on the Human Environment in Stockholm in 1972, where the Declaration of the United Nations Conference on the Human Environment was published, and environmental protection was established by the State (Mebratu 1988: 500-502). World environmentalism in the eighties began to focus not just on awareness about environmental protection, but also on the need to develop methods for solving ecological problems (Kośmicki 2007: 194).

An important global point in the development of the concept of sustainable development was the Earth Summit in Rio de Janeiro in 1992. It was adopted by 180 countries in the world Rio Declaration and Agenda 21. The first document included rules covering both the rights and duties of states (United Nations Conference on 


\section{Emilia BAMWENDA, Richard GIRLING}

Environment \& Development 1992). The second document is aimed at presenting the goals of shaping and protecting areas of the environment. Through appropriate and effective management of the implementation program of sustainable development, "Agenda 21" was to become a global blueprint setting out the directions of activities related to environmental management (United Nations Conference on Environment \& Development 1992: 3). Agenda 21's Ambition is a safe and just world in which every living being will be able to maintain its dignity (UNESCO 2006).

The next step towards sustainable development was The United Nations Millennium Summit in 2000, which saw the creation of the Millennium Development Goals. These were to be implemented by 2015 and among them were the goals of "Reducing extreme poverty and hunger by half; halving the number of people whose income does not exceed $1 \$$ per day; achieve universal primary education; provide for all people opportunities to complete a basic education; promote gender equality and empowerment of women; reduce child mortality reduce by $2 / 3$ mortality rate of child under 5 years of age; improve maternal health; limit the spread of HIV/AIDS, malaria and other diseases; sustainable management of natural resources; and create a global partnership for development" (Sachs, McArthur 2005: 347-348).

The next important step to develop the resolutions of the 2020 Strategy was The World Summit on Sustainable Development in Johannesburg In 2002, where the Action Plan and Political Declaration documents were adopted. The main element of this summit was the signing of the Action Plan, which obliged the signatories to strengthen the three main elements of sustainable development regarding social, economic and environmental development, which were to remain independent but mutually reinforcing pillars (Kimball et al. 2002: 3-13).

At the next Rio Earth Summit, Rio +20 , issues of global problems were taken into consideration, highlighted by demographic changes in the world. The conclusion of the negotiations was the formal acceptance of the "The State of the Future We Want" document, which highlighted in particular the problem of poverty in the world. During the conference, member states also agreed to the "Sustainable Development Goals after 2015", which were modeled after the "Millennium 
Development Goals", incorporating both their strengths and weaknesses (Sanchez, Croal 2012: 46-48).

\section{European concepts for sustainable development}

Sustainable development is the primary and overarching objective of the European Union - an objective which the EU has actively worked on since the formulation of global initiatives discussed in the previous section. The EU's task simultaneously revolves around economic development, environmental protection and social justice, which will result in deeper integration within the EU structure. The area of European activities is visible in the Amsterdam Treaty, the 2001 European Union Sustainable Development Strategy with subsequent amendments and revisions that complement the Lisbon Strategy, and the Europe 2020 Strategy.

With regards to the integration of sustainable development into the EU strategy, the first step was taken in 1997. This happened with the adoption of the Treaty of Amsterdam. The changes introduced to the Treaty were primarily related to the strengthening of the EU's federal form and the power of the European Parliament. The agreement has had an important impact on European politics as a whole, including the area of sustainable development. (Van Calster, Deketelaere 1998: 14).

The treaty defined common European values and set a common path for all member states. The Treaty of Amsterdam formalized the social dimension of sustainable development and included it in the legal framework binding all member countries (Sozański et al. 2002: 90-93). With regards to sustainable development, it was a landmark legal act in the history of EU documents. Therefore, sustainable development is in line with the basic values adopted by the European Union, which created the opportunity to develop the entire process of European integration.

Differences in global development have mobilized the union to embrace a new path. The EU's ambition to be the leading competitive economy in the world was to be completed by 2010. In 2000 in Lisbon, a social and economic development plan was developed by implementing economic legislation. The assumption of this concept was an economy capable of sustainable economic growth, based on a 


\section{Emilia BAMWENDA, Richard GIRLING}

knowledge-based economy (Kok 2004: 8-11). The provisions of Lisbon, in the newly adopted European policy, corresponded to the social dimension of sustainable development.

\section{European initiative for sustainable development}

At the summit in Gothenburg, European leaders debated about the vision for European sustainable development. The culmination of these deliberations was the adoption of the strategy for the sustainable development of the European Union, which was based mainly on proposals put forward by the European Commission. It was divided into two parts, the first of which dealt with the objectives of EU policy which currently oppose the idea of sustainable development. The second emphasized the need for changes in the process of creating European plans and policies in order to ensure the compatibility of economic, environmental and social policies. The provisions of the European Commission regarding the coherence of the strategy were to act as a catalyst, which would be a factor influencing the behavior of decision-makers as well as a society that is consistent with the idea of sustainable development (CEC 2001: 2-4).

Global changes and the identification of new challenges facing sustainable development have led to the need for a targeted strategy, transparent breakdown of responsibilities, effective monitoring and management. The new development strategy was to be a single, coherent strategy for fulfilling the European Union's commitment to address the challenges of sustainable development. In this version of the strategy, the importance of cooperation with partner countries outside the European Union was stressed, especially developing countries, and global solidarity in addressing the issue of sustainable development (Dalal-Clayton 2004: 15-20).

The Lisbon Agenda has been replaced by the Europe 2020 Strategy, which was adopted on June 17, 2010. From this moment, sustainable development was carried out within its framework with the intention of creating an economic and social plan that would significantly reduce social exclusion. Europe 2020 was also a plan to overcome the economic crisis and economic threats related to the prosperous 
development of Asian countries. The crisis in Europe affected society above all, in which 23 million people were unemployed in 2009. The deepening integration of countries also affected economic and economic instability. These factors have led to radical action and narrowing cooperation between Member States (Sulmicka 2011: 171-173). The assumptions of the Europe 2020 strategy, apart from creating measures to overcome the crisis, had much broader provisions allowing for creating a stable foundation for a sustainable future of the Community's development . It was to be a program that gives the opportunity to stabilize sustainable European development, using the strongest assets that Europe has.

\subsection{Europe 2020 goals}

The Europe 2020 strategy was designed to accelerate economic growth and employment by embracing the three main priorities. The first of these was intelligent growth, under which it is necessary to invest in a more innovative and knowledgebased economy (Sulmicka 2011: 172). The result was to be a modern society with a large number of high technology enterprises. The result would be benefits for entrepreneurs as well as for the entire economy. The next priority was sustainable growth characterized by a low-carbon economy, which at the same time increases its competitiveness. Environmentally-friendly activities were to be rewarded with the promotion of micro, small and medium-sized enterprises that are more competitive. The last priority was development based on reducing social exclusion. Within this priority, the economies with high employment rates were to be supported, which at the same time ensures social, economic and territorial cohesion. All these priorities are consistent with each other, and only introducing them at the same time guarantees achievement of the intended success (EC 2010: 11-13). For better monitoring of the implementation of changes, decision-makers created specific objectives that were to be adapted to the realities of each country. The first goal was to increase the employment rate aged $20-64$ from $69 \%$ to $75 \%$. The next objective is to maintain the current expenditure on research and development at 3\% of GDP, reduce greenhouse gas emissions by $20 \%$ compared to 1990 levels. Another objective is to reduce the rate of early school leaving to less than $10 \%$ and increase the number of people with higher education from $31 \%$ to $40 \%$. The fifth objective 
was to reduce the number of Europeans living in poverty by $25 \%$, or around 20 million people). The final goal is to reach $20 \%$ of the total energy consumption from renewable sources and increase energy efficiency by $20 \%$.

The Europe 2020 strategy was aimed at the inclusion of Member States with the stated goals and directions of development. They were part of the main idea of intelligent and sustainable development. Monitoring of the progress of this plan implementation was to be presented in the form of data that is reliable and measurable. The above goals indicate considerable consistency. An advantage of the Europe 2020 project is the adaptation and individual treatment of countries, taking into account their existing differences in their level of development. The current competitiveness of the European Union is based on the import and export of goods for the whole world. European actors, however, are aware of the increasingly stronger position of "Asian tigers", which may cause a decline in the competitiveness of Europe itself. Therefore, sustainable development is to contribute also to the external dimension of increasing competitiveness through better efficiency and maintaining the first position on environmentally friendly technologies markets (Sulmicka 2011: 179).

\subsection{Analysis of the achievement of the objectives}

Employment and other issues related to the labor market are the foundation of social and political debates. Employment is necessary to improve the quality of life and citizens' satisfaction. In addition, it contributes to economic growth as well as social inclusion as the basis for socioeconomic development and wellbeing. The Europe 2020 strategy, through its integration of economic growth, has set job creation as one of the five objectives and to raise employment rates of people between 20 to 64 years to $75 \%$.

As indicated in the above table, the distance to the $75 \%$ target decreased from 2010 to 3.9 percentage points. About $71.1 \%$ of the European population were employed in 2016 compared with 70.1\% In 2015 and 68.4\% in 2012, although it still remains slightly above the level of 2008. It is worth noting that in the case of men, this indicator reached the assumed level as early as in 2015. However, in comparison with other world economies, the EU is still lagging behind. It should 
also be noted that within 4 years from the creation of the strategy, this performance indicator was two times lower than in the year of its development. When considering the data in Table 1, it can be assumed that Europe may have a problem with achieving its objectives in this area. The employment of women is increasing steadily, but not fast enough to reach the set ceiling within four years. According to the Europe 2020 Strategy goals, the total employment rate for men and women is to be equal, which may raise concerns about the negative impact of this target on the fertility rate in an aging Europe. Thus, in the current situation, stimulating fertility may be equally as significant as reducing the high employment rate.

Table 1. Goal: $75 \%$ of the population aged 20-64 should be employed

\begin{tabular}{|c|c|c|c|c|c|c|c|c|}
\hline \multirow{2}{*}{\multicolumn{2}{|c|}{ Indicator/Unit }} & \multicolumn{6}{|c|}{ Year } & \multirow{2}{*}{$\begin{array}{c}\text { Aim } \\
\text { Europe } \\
2020\end{array}$} \\
\hline & & 2008 & 2010 & 2012 & 2014 & 2015 & 2016 & \\
\hline \multirow{3}{*}{$\begin{array}{l}\text { Employment } \\
\text { rate - age } \\
\text { group 20-64 }\end{array}$} & $\begin{array}{c}\% \text { of } \\
\text { population } \\
\text { aged 20-64 }\end{array}$ & 70.3 & 68.6 & 68.4 & 69.2 & 70.1 & 71.1 & \multirow{3}{*}{75} \\
\hline & Male & 77.8 & 75.2 & 74.5 & 75.0 & 75.9 & 76.9 & \\
\hline & Female & 62.8 & 62.1 & 62.4 & 63.5 & 64.3 & 65.3 & \\
\hline
\end{tabular}

Source: The authors own work based on Eurostat data.

Research on development and innovation is another Europe 2020 goal. The key element of activities in this area is the development of innovative products and services, not simply contributing to achieving the objectives of smart growth, but above all to sustainable development and integration. It is key to providing scientific and technical solutions that meet global social problems. In addition, they will bring new economic opportunities, sources of growth and jobs, and increase competitiveness, which will allow Europe to strengthen areas of cooperation between partner countries (EC 2010: 8-9). 
Table 2. Goal: 3\% of the EU's GDP should be invested in R\&D

\begin{tabular}{|c|c|c|c|c|c|c|c|}
\hline \multirow{2}{*}{ Indicator/Unit } & \multicolumn{6}{|c|}{ Year } & \multirow{2}{*}{$\begin{array}{l}\text { Aim } \\
\text { Europe } \\
2020\end{array}$} \\
\hline & 2008 & 2010 & 2012 & 2013 & 2014 & 2016 & \\
\hline $\begin{array}{c}\text { Gross domestic expenditure } \\
\text { on R\&D } \\
\% \text { of GDP }\end{array}$ & 1.85 & 1.93 & 2.01 & 2.02 & 2.03 & $2.3(\mathrm{p})$ & 3 \\
\hline
\end{tabular}

Source: The authors own work based on Eurostat data.

In the period of a slight increase in 2009-2014, research and development expenditures reached $2.4 \%$. As shown in Table 2, however, this progress was slow, and the latest data shows that since 2014 there is stagnation, moving the EU away from the 3\% target. The intensity of research and development has been slowly increasing after the EU crisis in connection with the increase in public funding in research and development in many member states. Also in this area, the EU is lagging behind global leaders. In order to achieve the Europe 2020 target, the EU must drive growth in $\mathrm{R} \& \mathrm{D}$ funding by at least 0.17 percentage points. In addition, the $R \& D$ expenditure ratio is related to the theory of endogenous growth, combining knowledge stemming from research and development activities with a permanent acceleration of economic growth. According to this theory, current investment in research is the main condition for accelerating future growth. One should not expect a quick effect, but one can expect a positive correlation with the time-shifted indicators that indicate long-term dependence. An additional problem also appears in the adopted index, which is a typical indicator of inputs, and yet the strategy is primarily about the effects. Despite the widespread use of such simplification, with regards to policy assessment, the EU generally distinguishes between indicators of inputs and effects.

The next education and training goal is the basis of the Europe 2020 strategy, the implementation of which will contribute to growth and employment. Europe in recent years has had to overcome the economic crisis and the aging population problem, which affects all other economic indicators. On the other hand, the area of education helps increase productivity, innovation and competitiveness. In addition, this objective is closely linked to other Europe 2020 strategies and, above all, to the 
above mentioned R\&D objective, as investments in the $R \& D$ sector are associated with demand for highly qualified employees.

Table 3. Goal: The share of early school leavers should be under $10 \%$ and at least 40\% of 30-34 years old should have completed a tertiary or equivalent education

\begin{tabular}{|c|c|c|c|c|c|c|c|}
\hline \multirow{2}{*}{ Indicator / Unit } & \multicolumn{6}{|c|}{ Year } & \multirow{2}{*}{$\begin{array}{l}\text { Aim } \\
\text { Europe } \\
2020 \\
\end{array}$} \\
\hline & 2008 & 2010 & 2012 & 2014 & 2015 & 2016 & \\
\hline $\begin{array}{c}\text { Early leavers from education } \\
\text { and training / \% of population } \\
\text { aged } 18-24\end{array}$ & 14.6 & 13.9 & 12.7 & 11.2 & 11.0 & 10.7 & 10 \\
\hline Male & 16.6 & 15.8 & 14.5 & 12.8 & 12.4 & 12.2 & \\
\hline \begin{tabular}{ll}
\cline { 2 - 2 } & Female \\
\end{tabular} & 12.6 & 11.9 & 10.9 & 9.6 & 9.5 & 9.2 & \\
\hline $\begin{array}{c}\text { Tertiary educational } \\
\text { attainment / \% of population } \\
\text { aged } 30-34 \\
\end{array}$ & 31.2 & 33.8 & 36.0 & 37.9 & 38.7 & 39.1 & 40 \\
\hline Male & 28.9 & 30.3 & 31.8 & 33.6 & 34.0 & 34.4 & \\
\hline Female & 34.4 & 37.3 & 40.2 & 42.3 & 43.4 & 43.9 & \\
\hline
\end{tabular}

Source: The authors own work based on Eurostat data.

As the above table indicates, the level early school leaving has been steadily decreasing since the year of the strategy development. This decrease applies to both women and men. In 2016, only 7 percentage points remain between the current and target level, which means that a large number of Member States have already achieved national targets. This objective also includes one more indicator referring to the completion of the third level of education. In this area, you can also see the progress which was to achieve state of $40 \%$. For 2016, the data already indicated the number of $39.1 \%$, which means that an increase by almost $6 \%$ was noted. It is also evident that in this case the goal was achieved by women who exceeded the $40 \%$ target already in 2012. This means that the goal is very likely to be achieved by 2020. However, the adopted indicators are typical quantitative indicators, qualitative factors like the quality and structure of education are also important. For example, the shortage of staff with technical education is significant, because European students are reluctant to choose more technical courses, in contrast to students from outside of Europe. 
The next priority is to prevent a spiral of social exclusion and poverty that creates more inequality which can in turn contribute to a permanent decline in the economic performance. The inability to lead a dignified life increases the risk of poverty. Therefore, effective development of education, health care, social systems, employment or tax breaks, may result in a risk of poverty passed down from generation to generation.

Table 4. Goal: Reduce poverty by drawing 20 million people from the risk of poverty and social exclusion

\begin{tabular}{|c|c|c|c|c|c|c|}
\hline \multirow{2}{*}{ Indicator } & Unit & \multicolumn{5}{|c|}{ Year } \\
\cline { 2 - 7 } & Millions & 2008 & 2012 & 2014 & 2015 & 2016 \\
\hline $\begin{array}{c}\text { People at risk of } \\
\text { poverty or social } \\
\text { exclusion }\end{array}$ & Thousand & - & 39711 & 41945 & 39839 & 38811 \\
\hline $\begin{array}{c}\text { People living in } \\
\text { household with } \\
\text { very low work } \\
\text { intensity }\end{array}$ & Thousand & - & 83953 & 85926 & 86752 & 87016 \\
\hline $\begin{array}{c}\text { People at risk of } \\
\text { poverty after } \\
\text { social transfers }\end{array}$ & Thousand & - & 49449 & 48034 & 44441 & 40361 \\
\hline $\begin{array}{c}\text { People severely } \\
\text { materially } \\
\text { deprives }\end{array}$ & Tyyyyyyy \\
\hline
\end{tabular}

Source: The authors own work based on Eurostat data.

The number of people living in poverty in 2010 was over 121 million. After 2013, the European economy started recovering after the crisis, but despite this, every fourth person living in Europe is affected by social exclusion or poverty. The decrease by 1 million compared to 2008 from 2016 is related to the EU economic problems which in 2012 caused regression in terms of reaching the Europe 2020 target. To increase the chances of meeting the target, the number of poor or socially excluded people must still decrease by 22.9 million, which may be difficult to achieve. After the presentation of the above objective, there were voices about the low probability of implementing such an ambitious strategy, in particular taking into 
account the failure of the implementation of the Lisbon Strategy, which did not bring any effects in the area of poverty reduction or social exclusion. Moreover, the method of calculating poverty adopted by Eurostat is quite controversial. $60 \%$ of the median national average equivalent income means a completely different financial situation between low income countries and rich countries.

Table 5. Goal: Reduce greenhouse gas emissions by $20 \%$ compared to 1990 levels. Attain a renewable energy rates of $20 \%$ of total energy consumption. Improve energy efficiency by $20 \%$

\begin{tabular}{|c|c|c|c|c|c|c|c|}
\hline \multirow{2}{*}{ Indicator / Unit } & \multicolumn{6}{|c|}{ Year } & Aim \\
\cline { 2 - 7 } & 2008 & 2010 & 2012 & 2013 & 2014 & 2015 & $\begin{array}{c}\text { Europe } \\
2020\end{array}$ \\
\hline $\begin{array}{c}\text { Greenhouse gas emission / } \\
\text { Index 1990=100 }\end{array}$ & 90.61 & 85.73 & 83.2 & - & 77.39 & 77.88 & 80 \\
\hline $\begin{array}{c}\text { Share of renewable energy } \\
\text { in gross final energy } \\
\text { consumption / \% }\end{array}$ & 11.0 & 12.5 & 12.9 & 15.0 & 16.1 & 16.7 & 20 \\
\hline $\begin{array}{c}\text { Primary energy consumption } \\
\text { /\% of saving }\end{array}$ & 2.8 & 5.7 & 9.4 & 11.9 & 16.1 & 16.7 & 20 \\
\hline
\end{tabular}

Source: The authors own work based on Eurostat data.

The goal of reducing greenhouse gas emissions by $20 \%$ has already been implemented between 2013 and 2014. The keys to reducing emissions can not only revive innovation but also create new jobs which is closely related to the goal of research and development as well as reduction of poverty and social exclusion. Quick progress has mobilized the EU to set a more demanding goal by 2050 , in which the EU is to become a low-carbon economy reducing greenhouse gas emissions by as much as $80-90 \%$. Steady progress has been noted for all of these goals which, if it continues, may result in achieving the 2020 targets. In this matter, there is a risk associated with reducing $\mathrm{CO} 2$ emissions. Member States whose energy is based largely on coal face an escalation of energy costs and a subsequent decrease in competitiveness of production, which will result in an increase in unemployment. 


\section{Concluding remarks}

The EU Action Plan shows the way to a long-term vision of sustainable development. Economic development, social cohesion and environmental protection are to become mutually complementary elements, which in the understanding of European strategies are to be monitored in a transparent and easy way. However, in order to be effective it is not enough to just set a specific action plan, monitored by selected entities. It's necessary to also develop a management system, requiring Member State to implement controls and requirements in their policies. It is necessary to adapt the Europe 2020 targets individually to each Member State, taking into account their current level of social and economic development. The creation of a proper system of sustainable development indicators may better guide the implementation of the plan's objectives by 2020. The assessment of progress presented in this article indicates that positive changes are visible primarily in terms of employment indicators, greenhouse gas emissions and the use of renewable energy. However, there has been a lack of progress in terms of poverty and social exclusion. All of the aforementioned goals share a common problem: Namely, that the numerical goals set were all arbitrarily assigned. Another important issue is the insufficient involvement of Member States in the policy of sustainable development. Often, sustainable development takes a back seat to the main policies in which national actors mainly focus on the promotion and growth of their own economies.

Additionally, there is a lack of readiness among Member States to bear the related financial and political costs of implementing some of the objectives. The dynamics of the internal integration processes of the European Union are significantly influenced by a number of factors. The most important factor affecting the transformation of the European Union is the adoption of sustainable development objectives, specifically increasing the international competitiveness of the EU, as well as strengthening cooperation within the EU and creating social and economic conditions for the European Union. It is therefore necessary to move away from the traditional model of European integration shaped on the original concept of the Schuman plan. In order to adapt to an increasingly globalized world, EU Member States must act as a whole, adapting to coherent concepts. As one body, the 
European Union is able to influence the challenges of globalization and influence economic, social and technological issues.

For many supporters of the European project, the EU has entered a period of stagnation and even regression. Many experts and scientists believe that a probable EU disintegration is inevitable, and - even in the event of survival - the shape and nature of European integration will be questioned. On the other hand, there is also some optimism that these crises, in the face of the EU, can bring about beneficial reforms and ultimately make the Union more effective and coherent. The enlargement of the Union has highlighted the existing discrepancies between Member States, hence the need to apply modern mechanisms to support integration processes adapted to each member country. The sustainable development discourse has been discussed many times during the debates of the European institutions, as well as within the framework of various strategies for adapting it to European conditions. Therefore, the concept of sustainable development can play an important role in the activities of the European Union, representing a new form of integration.

\section{References}

Commission of the European Communities (CEC) (2001), A sustainable Europe for a better world. A European Union strategy for sustainable development, COM 264 final, http://ec.europa.eu/regional_policy/archive/innovation/pdf/library/strategy_sustdev_en.pdf [17.03.2018].

CEC (2005), Summary of the public consultation for the review of the European Sustainable Development Strategy 2001, „European Commission Staff Working Document” SEC (2005)451 final.

Dalal-Clayton B. (2004), The EU strategy for sustainable development. Process and prospects, „Environmental Planning Issues”, no. 27, http://www.environmentalmainstreaming.org/nssd/pdf/eustrategy_14jan2004.pdf [17.03.2018].

EUFacts (2010), Europe 2020. A European strategy for smart, sustainable, and inclusive growth, „EU Fact Sheet", http://ec.europa.eu/eu2020/pdf/COMPLET\%20EN\%20BARROSO\%20\%20\%20007\%20\%20Europe\%202020\%20-\%20EN\%20version.pdf [17.03.2018].

European Commission (EC) (2010), A strategy for smart, sustainable and inclusive growth, „European Commicion Staff Working Document” COM (2010) 2020 final.

EC (2018), http://ec.europa.eu/eurostat/cache/Euro_2020/E2020_EN.html\# [17.03.2018]. 


\section{Emilia BAMWENDA, Richard GIRLING}

European Union (EU) (2011), Territorial agenda of European Union 2020, http://www.nweurope.eu/media/1216/territorial_agenda_2020.pdf [16.03.2018].

Eurostat (2017), http://ec.europa.eu/eurostat/web/europe-2020-indicators/europe-2020strategy/headline-indicators-scoreboard [17.03.2018].

Kimball L., Perez F.X., Werksman J. (2002), The results of the World Summit on Sustainable Development. Targets, institutions and trade implementation, Oxford University Press, Oxford, pp. 313 .

Kok W. (2004), Facing the challenge. The Lisbon strategy for growth and employment, „Office for Official Publication of the European Communities", Luxemburg.

Kośmicki E. (2007), Geneza koncepcji trwałego i zrównoważonego rozwoju (The origin of the concept of permanent and sustainable development), Wydawnictwo Wyższej Szkoły w Białymstoku, Białystok.

Mebratu D. (1998), Sustainability and sustainable development. Historical and conceptual review, „Environmental Impact Assessment Review”, vol. 18 no. 6, pp. 493-520.

Norgard R.B. (1994), Development betrayed. The end of progress and coevolutionary revisioning of the future, „American Journal of Agricultural Economics”, vol. 77 no. 2, p. 435.

Parlament Europejski (EP), Strategia Lizbońska. Zwiększenie konkurencyjności Europy, więcej lepszych miejsc pracy, http://www.europarl.europa.eu/highlights/pl/1001.html [17.03.2018].

Płachciak A. (2011), Geneza idei rozwoju zrównoważonego (The origin of sustainable development idea), „Wydawnictwo Uniwersytetu Ekonomicznego we Wrocławiu: Ekonomia”, vol. 5 no. 17, pp. 231-248,

http://www.dbc.wroc.pl/Content/26014/Plachciak_Geneza_idei_rozwoju_zrownowazonego.pdf [17.03.2018].

Rokicka E., Woźniak W. (2016), W kierunku zrównoważonego rozwoju. Koncepcje, interpretacje, konteksty (Towards sustainable development. Concepts, interpretations, context), Katedra Socjologii Ogólnej Uniwersytetu Łódzkiego, Łódź, http://socjologia.uni.lodz.pl/pliki/32w_kierunku_zrownowazonego_rozwoju.pdf [17.03.2018].

Sachs J.D., McArthur J.W. (2005), The Millennium Project. A plan for meeting the Millennium Development Goals, „The Lancet”, vol. 365 no. 9456, pp. 347-348.

Sanchez L.E., Croal P. (2012), Environmental impact assessment, from Rio-92 to Rio 20+ and beyond, „Ambiente \& Sociedade”, vol. 15 no. 3, pp. 46-48.

Sozański J. (2002), Standardy zrównoważonego rozwoju i wspólnotowej polityki ochrony środowiska na tle obowiązków państw kandydujących do Unii (Standards of sustainable development and Eruopean environmental policy in the light of the obligations of the candidate countries to the EU), in: Zasada zrównoważonego rozwoju $\mathrm{w}$ prawie i praktyce ochrony środowiska (The principle of sustainable development in the law and practice of protection of the environment), K. Równy, J. Jabłoński (ed.), Wydawnictwo PWSBiA, Warszawa, pp. 90-93. 


\section{IMPLEMENTATION OF THE SUSTAINABLE DEVELOPMENT GOALS ...}

Sulmicka M. (2011), Strategia „Europa 2020”. Postlizbońska polityka rozwoju Unii Europejskiej (The Europe 2020 Strategy. Post-Lisbon policy of European Union development), „Prace i Materiały Instytutu Rozwoju Gospodarczego SGH”, no. 85, pp. 169-190.

The World Commission on Environment and Sustainable Development (1987), Our common future. Report, http://www.un-documents.net/our-common-future.pdf [17.03.2018].

UNESCO (Polski Komitet ds. UNESCO) (2006), UNESCO a dekada edukacji dla zrównoważonego rozwoju, http://www.unesco.pl/edukacja/dekada-edukacji-nt-zrownowazonego-rozwoju/unesco-azrownowazony-rozwoj/ [17.03.2018].

United Nations Conference on Environment \& Development (1992), Earth Summit, Rio de Janerio, 314 June. Report, http://www.un.org/geninfo/bp/enviro.html [17.03.2018].

Główny Urząd Statystyczny (GUS) (2011), Wskaźniki zrównoważonego rozwoju Polski (Indicators of sustainable development in Poland), Główny Urząd Statystyczny, Katowice.

Van Calster G., Deketelaere K. (1998), Amsterdam, The Intergovernmental Conference and Greening the EU Treaty, „European Energy and Environmental Law Review”, vol. 7 no. 1, pp. 12-25.

Internet source:

http://eur-lex.europa.eu/legalcontent/PL/TXT/HTML/?uri=LEGISSUM:128157\&from=PL [17.07.2017].

http://www.unmillenniumproject.org/documents/131302_wssd_report_reissued.pdf [14.07.2017]. 